ARTICLE

Received 17 Jul 2012 | Accepted 20 Dec 2012 | Published 29 Jan $2013 \quad$ DOl: 10.1038/ncomms2414

\title{
The Tissint Martian meteorite as evidence for the largest impact excavation
}

loannis P. Baziotis ${ }^{1}$, Yang Liu'1,2, Paul S. DeCarli ${ }^{3}$, H. Jay Melosh ${ }^{4}$, Harry Y. McSween¹, Robert J. Bodnar ${ }^{5}$ \& Lawrence A. Taylor ${ }^{1}$

High-pressure minerals in meteorites provide clues for the impact processes that excavated, launched and delivered these samples to Earth. Most Martian meteorites are suggested to have been excavated from 3 to $7 \mathrm{~km}$ diameter impact craters. Here we show that the Tissint meteorite, a 2011 meteorite fall, contains virtually all the high-pressure phases (seven minerals and two mineral glasses) that have been reported in isolated occurrences in other Martian meteorites. Particularly, one ringwoodite $\left(75 \times 140 \mu \mathrm{m}^{2}\right)$ represents the largest grain observed in all Martian samples. Collectively, the ubiquitous high-pressure minerals of unusually large sizes in Tissint indicate that shock metamorphism was widely dispersed in this sample $\left(\sim 25 \mathrm{GPa}\right.$ and $\left.\sim 2,000^{\circ} \mathrm{C}\right)$. Using the size and growth kinetics of the ringwoodite grains, we infer an initial impact crater with $\sim 90 \mathrm{~km}$ diameter, with a factor of 2 uncertainty. These energetic conditions imply alteration of any possible low- $T$ minerals in Tissint.

\footnotetext{
${ }^{1}$ Planetary Geosciences Institute, Department of Earth and Planetary Sciences, University of Tennessee, Knoxville, Tennessee 37996, USA. ${ }^{2}$ Jet Propulsion Laboratory, California Institute of Technology, Pasadena, California 91109, USA. ${ }^{3}$ Poulter Laboratory, SRI International, Menlo Park, California 94025, USA. ${ }^{4}$ Department of Earth, Atmospheric and Planetary Sciences, Purdue University, West Lafayette, Indiana 47907, USA. ${ }^{5}$ Department of Geosciences, Virginia Tech, Blacksburg, Virginia 24061, USA. Correspondence and requests for materials should be addressed to L.A.T. (email: lataylor@utk.edu).
} 
$\mathrm{T}$ he shock-induced, high-pressure phases in Martian meteorites have been used to estimate the dynamics of the impacting bolides and the size of the resulting craters on Mars ${ }^{1-3}$. To date, the high-P phases observed in Martian meteorites include impact-produced glass (maskelynite from plagioclase and pyroxene-composition glass), ringwoodite ( $\gamma$-polymorph of olivine), akimotoite (ilmenite structure of pyroxene), lingunite (Na-hollandite structure of plagioclase), majorite (garnet structure of pyroxene), tuite ( $\gamma$-polymorph of merrillite), stishovite $\left(\alpha-\mathrm{TiO}_{2}\right.$ structure of quartz) and silicate perovskite (perovskite structure of pyroxene). Most of the high-P phases are polymorphs (more densely packed structure) than the low-P minerals that are listed in brackets above. These high-P phases are typically small $(<10 \mu \mathrm{m})$ and were only observed in isolated occurrences in or near shock-induced melts within the meteorites (Table 1). Tissint was named for a 2011 meteorite fall in Morocco, near the village of Tissint, and was identified to be a Martian meteorite ${ }^{4}$. Being the freshest Martian sample, this meteorite has generated great interest in the community for the possibility of detecting signs of prior Martian life.

We have conducted a detailed study on eight (8) serial sections from a $10 \mathrm{~g}$ piece of this meteorite, which was totally covered by fusion crust. These sections essentially provide a three-dimensional tomography of the sample. After noticing a large ringwoodite grain in a melt pocket, we carefully examined other impact-melt pockets and veins using optical microscopy for texture and mineralogy, electron microprobe (EMP) for chemistry and in situ micro-Raman spectroscopy for definite proof of the structures. Compared with those in the literature data on the structure of similar phases, the chemical and crystal structure information obtained with these coupled methods provide positive identification of the high-P phases (the Supplementary Information). We observed all nine (9) of the previously identified high-P phases to be present in this single shergottite. The wide occurrence of these high-P phases and their unusually large sizes indicate shock pressures and temperatures of $\sim 25 \mathrm{GPa}$ and $>2,000^{\circ} \mathrm{C}$ throughout the sample concentrating in the melt pockets. Based on the size and growth rate of ringwoodites, we infer that this sample was excavation and launched from an impact generated by a crater of $\sim 90 \mathrm{~km}$ diameter (a factor of 2 uncertainty). This inferred crater size is much larger than that estimated for all other shergottites $(3-7 \mathrm{~km})$ (ref. 4) to date.

\section{Results}

Mineralogy. The mineralogy and petrography of Tissint resemble other olivine-phyric shergottites (details in the Supplementary
Information) and other pieces of the same fall ${ }^{5,6}$. Detailed mineralogy and petrography of Tissint from our study will be reported elsewhere, but a brief summary is given in the Supplementary Information.

Shock features. Shock features in Tissint are abundant and are suggestive of strong shock metamorphism. All olivines display unusual reddish-brown to black colour imparted by submicron Fe or $\mathrm{Fe}-\mathrm{O}$ grains formed by shock ${ }^{7}$. Some olivines display undulatory extinction, mosaicism and planar deformation features (PDFs), especially as planar cleavages. PDFs in pyroxenes are clearly visible under crossed-polarized light. Shock-induced glass is also widespread (Supplementary Fig. S1). All plagioclase has been converted to: (a) maskelynite, a diaplectic glass formed by solid-state transformation ${ }^{8}$ or (b) glass quenched from shock-induced melting 9 . Thin melt veins of mafic compositions are also present and occasionally emanate from melt pockets (Supplementary Table S3).

High-pressure minerals. The most distinctive evidence of strong shock is the abundant (2-4 vol. \%) melt pockets and their associated high-P minerals (Table 1 and Supplementary Table S2). The sizes of the melt pockets range from $100-350 \mu \mathrm{m}$ in width and $160-1,000 \mu \mathrm{m}$ in length. These melt pockets are predominantly associated with olivine grains, residing between the interface of olivine and other minerals. Serial cutting and preparation of thin sections indicate that some melt pockets are interconnected over distances $>500 \mu \mathrm{m}$.

The high-P minerals observed in Tissint include ringwoodite, vitrified perovskite, akimotoite, majorite, lingunite, tuite and stishovite, occurring in different sizes, modes and locations (Figs 1-3, Tables 1 and 2 and the Supplementary Information). An unusually large green-coloured ringwoodite grain $\left(75 \times 140 \mu \mathrm{m}^{2}\right)$ resides in the edge of a melt pocket (Fig. 1); this is the largest ringwoodite observed in Martian meteorites. Other ringwoodite grains occur as individual smaller grains or thin rims $(10-20 \mu \mathrm{m})$ along contacts between olivine and the impact-melt pockets (Supplementary Fig. S4), or intergrown with vitrified perovskite in isolated ellipsoidal clasts in a melt pocket (Fig. 2). This is the first report of vitrified perovskite associated with ringwoodite in a Martian sample. The vitrified perovskite also occurs as rims on melt pockets (Supplementary Figs S4 and S5).

Akimotoite was identified as a small crystal $(2-3 \mu \mathrm{m})$ replacing the rim of a low-Ca pyroxene fragment (Fig. 2). It is entrained at the centre of a large melt pocket $(\sim 530 \times 350 \mu \mathrm{m})$ in close

Table 1 | High-P phases ( $x$ if present) in Martian meteorites. ${ }^{*}$

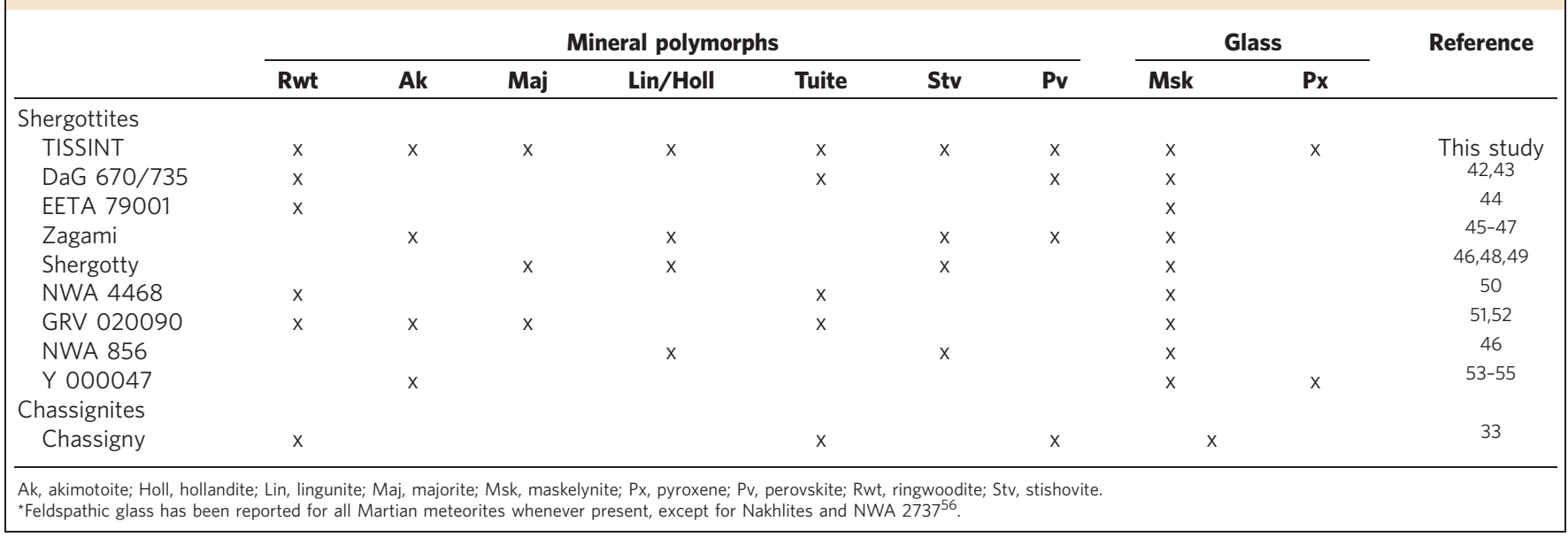



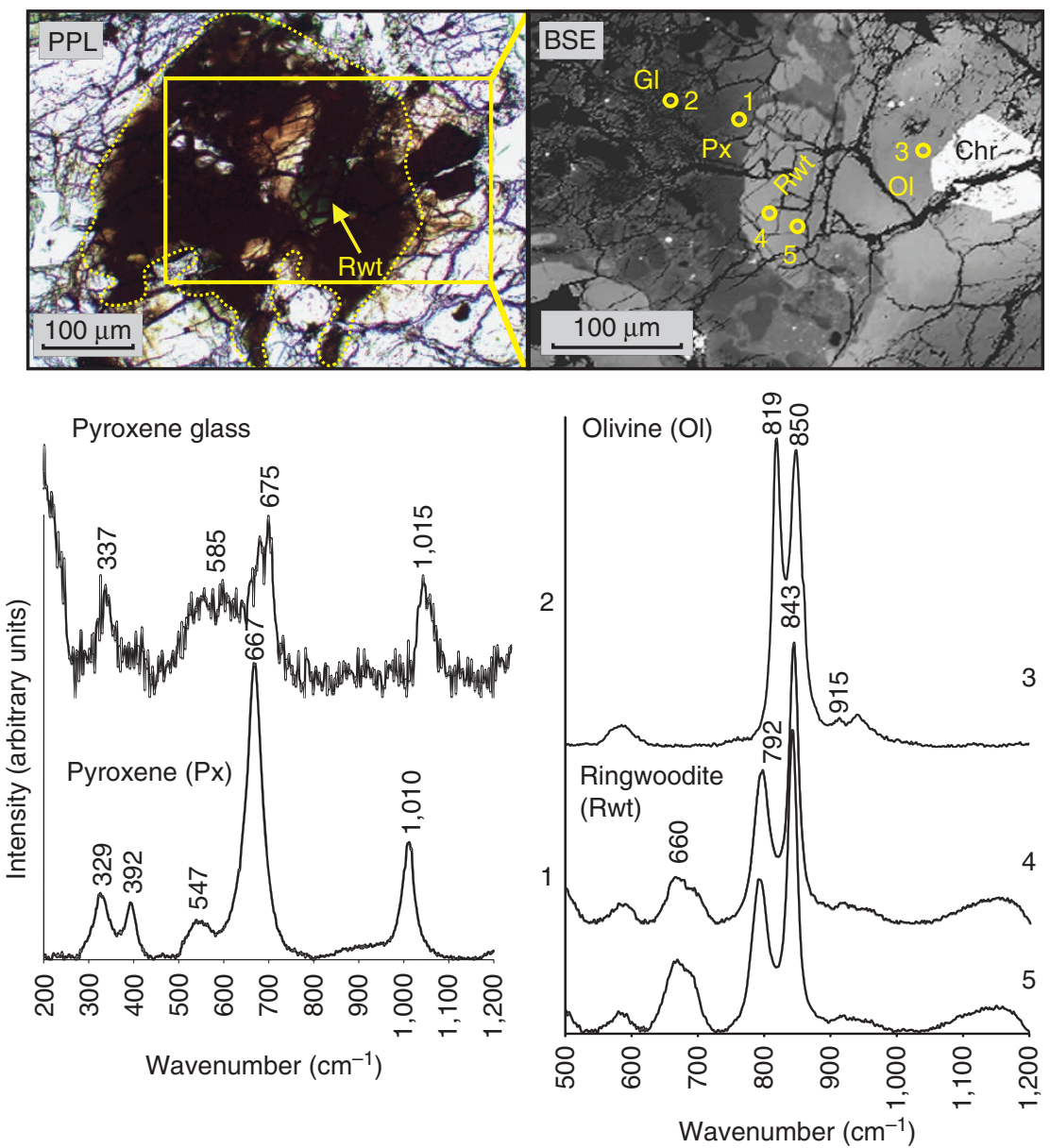

Figure 1 | A ringwoodite crystal within an impact-melt pocket. The green-coloured ringwoodite (olivine, $75 \times 140 \mu \mathrm{m}^{2}$ ) crystal is shown within a large impact-melt pocket $\left(400 \times 350 \mu \mathrm{m}^{2}\right)$. This crystal is isotropic under cross-polarized light. Selected chemical analyses are listed in Table 1, and more details are given in the Supplementary Information. Raman spectra of this crystal (spot no. 4 and no. 5) show characteristic absorption bands for ringwoodite. The low-P polymorph of olivine nearby displays a different structure (spot no. 3). Numbers next to circles indicate the respective Raman spots.

contact with ringwoodite + vitrified perovskite. Majorite and lingunite $(1-2 \mu \mathrm{m})$ were observed as polycrystalline aggregates entrained in a plagioclase-glass matrix (maskelynite), surrounded by tiny sulphide droplets (Fig. 3). This is also the first report of majorite and lingunite in a Martian meteorite.

Additionally, tuite occurs as minute single crystals $(2-3 \mu \mathrm{m}$ in size; Fig. 3) or associated with low-Ca pyroxene in replacement of merrillite (Supplementary Fig. S5). Stishovite is associated with olivine inside a melt pocket (Supplementary Fig. S6). In addition to the high-P minerals, the centre of an impact-melt pocket also contains dendritic crystals $(2-3 \mu \mathrm{m})$ with a pyroxene-like glass alternating with bright, olivine-like dendrites. The Raman spectra of the regions between the dendrites correspond to a pyroxenelike glass with two predominant broad peaks centred at 664 and $1,011 \mathrm{~cm}^{-1}$ (Supplementary Fig. S4).

\section{Discussion}

The diverse array of high-P phases and shock features in Tissint, integrated as a whole assemblage, provides tight and consistent constraints on the P-T conditions of shock metamorphism. The shock features in olivines and pyroxenes (undulatory extinction and mosaicism in olivines, PDF, nano-inclusions in olivines) indicate shock pressures of 26-32 GPa. The presence of shock melts suggests localized temperatures of $>1,750^{\circ} \mathrm{C}$. Previously, the formational conditions for maskelynite have been suggested to be a pressure $>40 \mathrm{GPa}$ (ref. 10). However, more recent studies suggested substantially lower pressures ${ }^{11}$, especially for those formed at higher temperature ${ }^{12}$. Using the method of Fritz et al., ${ }^{13}$ intensity ratios of Raman bands $586-507 \mathrm{~cm}^{-1}$ of maskelynite in Tissint suggest shock pressures between 26 and $40 \mathrm{GPa}$.

The maximum shock pressure and temperature, as constrained by the former perovskite, are $25-40 \mathrm{GPa}$ and $\gg 2,000{ }^{\circ} \mathrm{C}$, respectively ${ }^{14-17}$. Other occurrences of high-P minerals indicate shock pressures of $13-25 \mathrm{GPa}$ and temperatures of 1,700$2,600{ }^{\circ} \mathrm{C}$ in melt pockets ${ }^{17-25}$. Furthermore, the absence of lingunite decomposition products (calcium ferrite-type $\mathrm{NaAlSiO}_{4}+$ stishovite) suggests a P-T upper limit of $24 \mathrm{GPa}$ at $\sim 1,800-2,000{ }^{\circ} \mathrm{C}$ (refs 26,27 ). Overall, allowing for the uncertainty in applying available static high-pressure data to Tissint, we derived a peak pressure of $\sim 25 \mathrm{GPa}$ and temperature of $\sim 2,000{ }^{\circ} \mathrm{C}$, with localized shock reaching $40 \mathrm{GPa}$ and $\gg 2,000{ }^{\circ} \mathrm{C}$.

High-P minerals are formed under the intense pressures and temperatures provided by shock. After their formation, rapid cooling is needed to preserve these phases metastably at low pressure and temperature ${ }^{11}$. Previous studies have estimated the 'impact duration', using the size and chemical information of high-P minerals. Beck et al. ${ }^{2}$ obtained a shock duration of $10 \mathrm{~ms}$ for Zagami, based on diffusion profiles of $\mathrm{Cs}, \mathrm{Ba}$ and $\mathrm{Rb}$ near K-hollandite aggregates; they suggested the crater size to be $1.5-5 \mathrm{~km}$. Other studies ${ }^{28-30}$ inferred longer shock durations of 

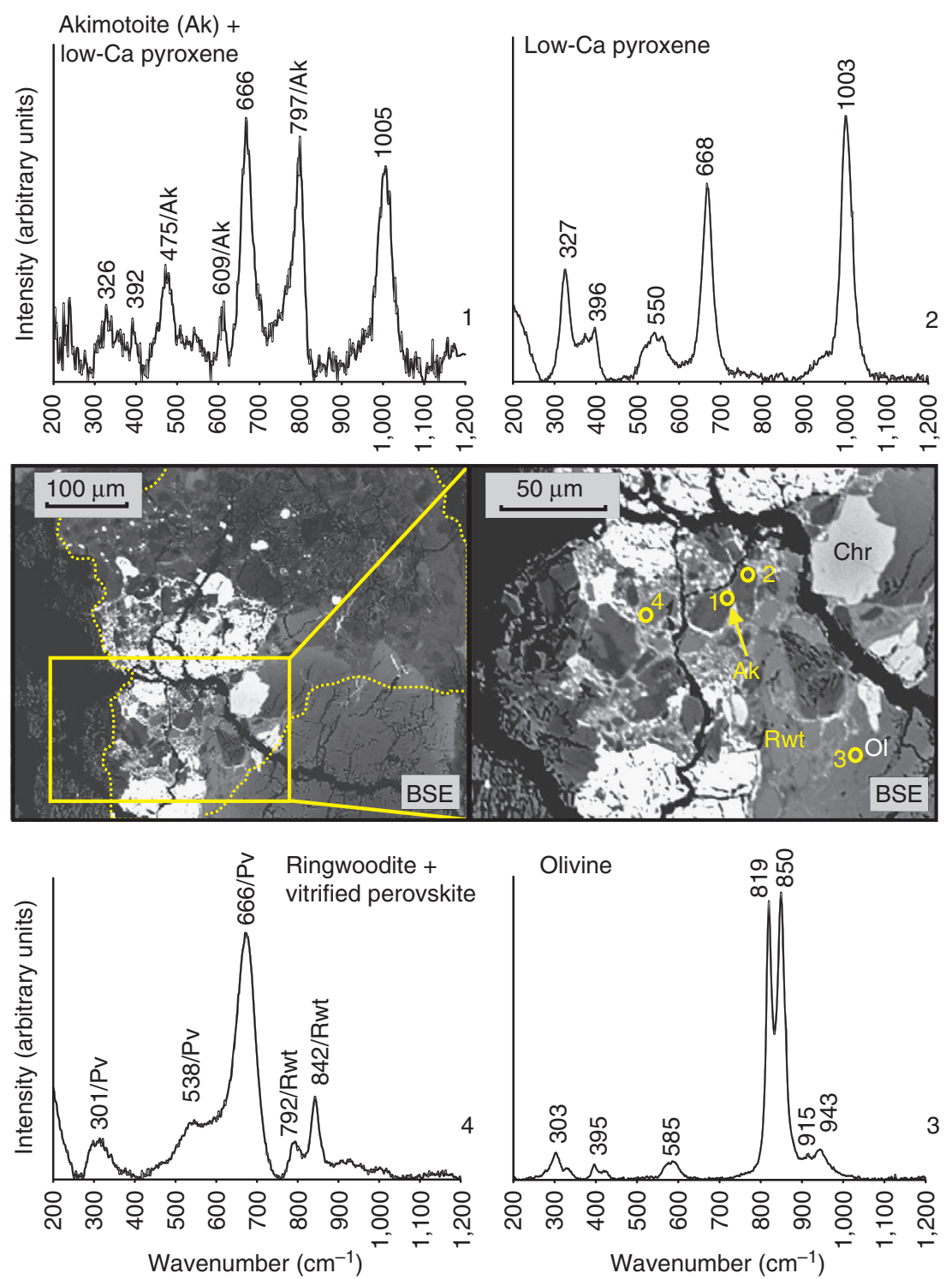

Figure 2 | High-pressure minerals in the Tissint meteorite. Akimotoite (Ak), ringwoodite (Rwt) and vitrified perovskite in an impact-melt pocket. Ringwoodite was identified in both the centre (no. 4) and rim of the impact-melt pocket. Raman spectra of the low-P equivalents (low-Ca pyroxene and olivine) are shown for comparison (no. 2 and no. 3). Bright minerals within the impact-melt pocket were identified using coupled EMP and Raman spectroscopy as pyrrhotite. Numbers next to the circles indicate the Raman spot analyses.

seconds to minutes for chondrites from the size of high-P minerals and interface-controlled growth rate ${ }^{31}$. In contrast, however, shock experiments on porous $\mathrm{MgO}$ and fused quartz produced $1-3 \mu \mathrm{m}$ wadsleyite in $<1 \mu$ s (ref. 32). This was used to argue that shock duration is much shorter for wadsleyite that grew from shock-formed melt (growth rate of $1 \mathrm{~m} \mathrm{~s}^{-1}$ ) (ref. 32). It is unclear whether this rapid rate is applicable to ringwoodite, which is a higher pressure polymorph than wadsleyite. In our sections of Tissint, wadsleyite is absent.

Thermodynamic data are available only for interface-controlled growth of ringwoodites ${ }^{30,31}$. Using the parameters in Mosenfelder et al., ${ }^{31}$ the ringwoodite growth rate is $\sim 2 \mu \mathrm{m} \mathrm{s}^{-1}$. Given the observed range, an average size of ringwoodite of $2 \mu \mathrm{m}$ corresponds to $\sim 1 \mathrm{~s}$. The largest ringwoodite (Fig. 1) cannot be explained by interface-controlled growth, and is likely a result of solid-state transformation or crystallization from shock-formed melt. Therefore, this grain was not used to constrain the shock duration. As the interface-controlled growth is likely more sluggish than solid-state transformation or crystallization from a liquid, the shock durations estimated above may be grossly overestimated. However, the large sizes of ringwoodite in Tissint likely reflect prolonged shock durations. After heating, rapid cooling was achieved in $\sim 50 \mathrm{~ms}$ for the centre of the melt pocket and $\sim 20 \mathrm{~ms}$ for the rim of the pocket (Supplementary Fig. S7), rendering conditions capable of preserving the high-P minerals observed.

Shock durations have been used to infer the burial depth of the original rock within the Martian crust, as well as the impactor size ${ }^{2,33}$. The impactor size is estimated using $D_{\text {impactor }}=\tau \times v$, where $\tau$ is the shock duration and $v$ is the impact velocity ${ }^{2}$. Using an average impact velocity of $10 \mathrm{~km} \mathrm{~s}^{-1}$ on Mars, the impactor size is $10 \mathrm{~km}$. The crater diameter can be approximated using a pi-scaling relation of Melosh ${ }^{34}$,

$$
D_{\text {crater }}=1.8 \times \rho_{\text {proj }}^{0.11} \times \rho_{\text {target }}^{-1 / 3} \times g^{-0.22} \times D_{\text {proj }}^{0.13} \times W^{0.22},
$$



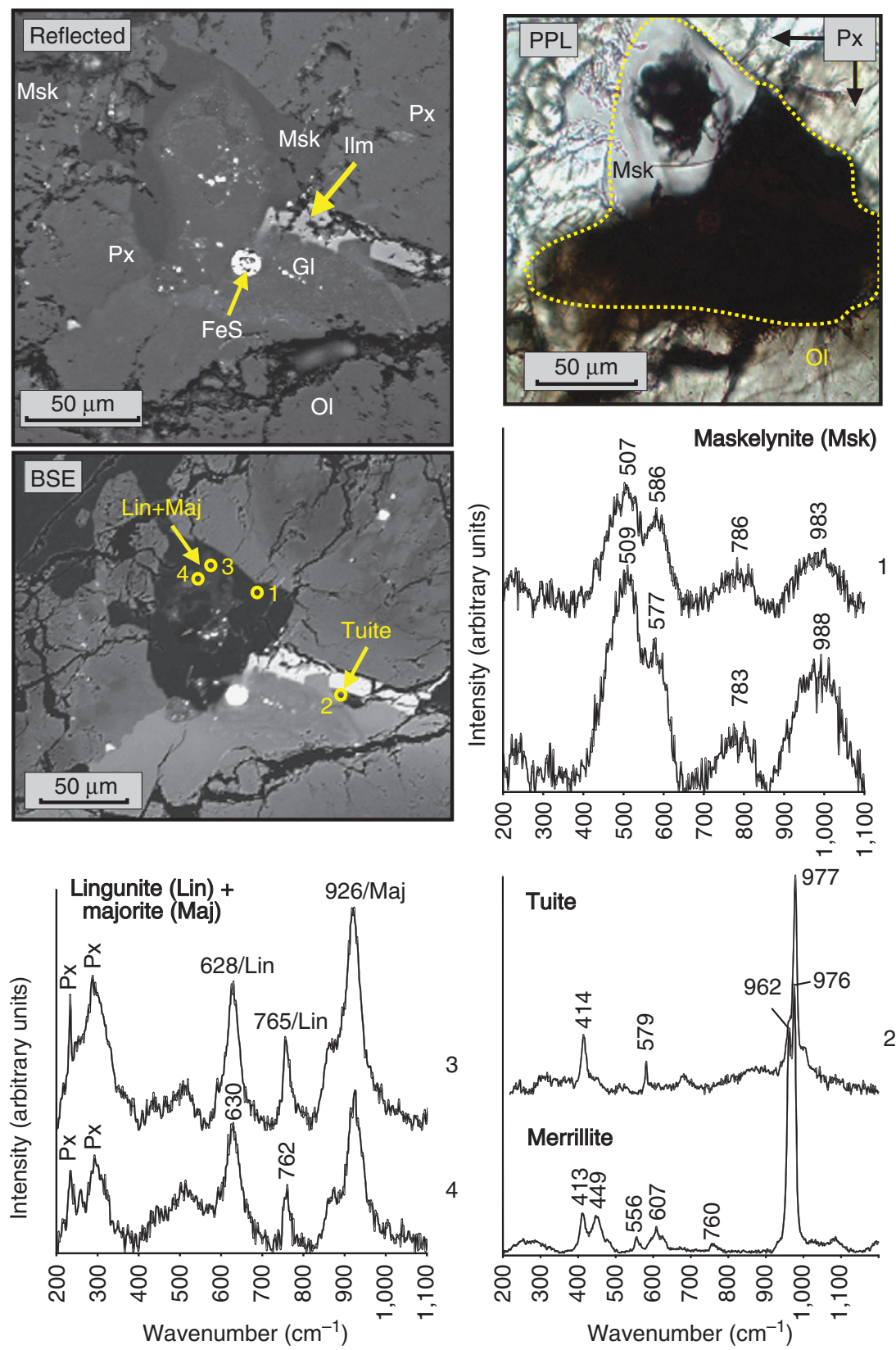

Figure 3 | Majorite and lingunite in a Martian meteorite. Majorite (Maj), lingunite (Lin) and tuite in an impact-melt pocket. Majorite and lingunite occur in a small plume that originated from the dark impact-melt pocket and intruded into the maskelynite (Msk). For comparison, Raman spectra of these high-P phases were plotted with the low-pressure ones from the groundmass. Numbers next to the circles indicate the Raman analysis spots.

where $D_{\text {proj }}=\tau \times v_{\text {proj }}, W$ is pure kinetic energy, $\rho_{\text {proj }}$ is the density of the impactor $\left(3,700 \mathrm{~kg} \mathrm{~m}^{-3}\right), \rho_{\text {target }}$ is the density of the basaltic target $\left(2,800 \mathrm{~kg} \mathrm{~m}^{-3}\right)$ and acceleration gravity $(g)$ on Mars $\left(g=3.72 \mathrm{~m} \mathrm{~s}^{-2}\right)$. The crater size resulted by the impactor estimated above is $\sim 90 \mathrm{~km}$. The validity of this estimate depends upon the complex nonlinear process of shock compression and release in the vicinity of a large impact. However, a process has yet to be addressed and modelled using detailed studies with realistic geometries and equations of state. Therefore, this cratersize estimate, conservatively, might be in error by as much as a factor of 2 .

Shergottites of similar cosmic-ray exposure (CRE) ages have been regarded to be derived from the same source crater ${ }^{4}$. The CRE age of Tissint (0.7 $\pm 0.3 \mathrm{Myr}$ (ref. 6) and $1.10 \pm 0.15 \mathrm{Myr}$ (refs 35,36)) is similar to several other olivine-phyric shergottites (for example, EET 79001 NWA 1068, Y 980459 and DaG 476/ 489, ref. 37). Considering the uncertainty, the estimated crater for Tissint is $>15 \times$ larger than those suggested for the other shergottites $(\sim 3 \mathrm{~km})^{4}$. For those with similar CRE ages, it appears to be contradictory to the previous suggestion. However, none of these shergottites have been thoroughly investigated for their high-P polymorphs. It is more likely that Tissint was launched in the higher-P and higher-T portion of the landing site of the impactor, with other shergottites of the similar CRE age being in proximal less-intense positions of the same crater (ref. 38). In such case, the high- $\mathrm{P}$ minerals and glasses of Tissint provide a better and more accurate estimation of the crater size as the potential source of the Shergottites. Compared with other 
Table 2 | Representative high-P mineral compositions with the related low-P equivalent.

\begin{tabular}{|c|c|c|c|c|c|c|c|c|c|c|}
\hline $\begin{array}{l}\text { Mineral } \\
\text { Analysis no. }\end{array}$ & $\begin{array}{l}\text { Ol } \\
1\end{array}$ & $\begin{array}{c}\text { Rwt } \\
2\end{array}$ & $\begin{array}{c}\text { Px } \\
3\end{array}$ & $\begin{array}{l}\text { GI } \\
4\end{array}$ & $\begin{array}{c}\text { Ak } \\
5\end{array}$ & $\begin{array}{c}v-P v \\
6\end{array}$ & $\begin{array}{c}\text { Mer } \\
7\end{array}$ & $\begin{array}{c}\text { Tuite } \\
\mathbf{8}\end{array}$ & $\begin{array}{c}\text { Msk } \\
9\end{array}$ & $\begin{array}{c}\text { Lin }+ \text { Maj } \\
10 \\
\end{array}$ \\
\hline $\mathrm{SiO}_{2}$ & 35.8 & 35.9 & 51.3 & 53.0 & 52.6 & 51.3 & $<0.03$ & 0.36 & 52.3 & 51.6 \\
\hline $\mathrm{TiO}_{2}$ & - & - & 0.35 & 0.22 & 0.19 & 0.33 & - & - & 0.07 & 0.16 \\
\hline $\mathrm{Al}_{2} \mathrm{O}_{3}$ & - & - & 1.03 & 1.10 & 0.73 & 1.08 & - & 0.56 & 29.6 & 24.0 \\
\hline $\mathrm{Cr}_{2} \mathrm{O}_{3}$ & 0.08 & 0.07 & 0.41 & 0.62 & 0.45 & 0.40 & - & - & - & - \\
\hline $\mathrm{FeO}$ & 36.5 & 36.7 & 22.9 & 16.6 & 21.6 & 22.1 & 3.82 & 2.13 & 0.76 & 5.6 \\
\hline $\mathrm{MnO}$ & 0.60 & 0.63 & 0.69 & 0.61 & 0.65 & 0.70 & 0.14 & 0.07 & $<0.04$ & 0.09 \\
\hline $\mathrm{MgO}$ & 27.1 & 26.9 & 18.3 & 20.7 & 19.7 & 17.7 & 2.28 & 3.32 & 0.12 & 1.95 \\
\hline $\mathrm{CaO}$ & 0.30 & 0.27 & 5.31 & 7.37 & 4.70 & 6.10 & 46.5 & 47.0 & 12.9 & 11.6 \\
\hline $\mathrm{Na}_{2} \mathrm{O}$ & - & - & 0.06 & 0.05 & 0.05 & 0.09 & 0.65 & 0.95 & 3.80 & 3.02 \\
\hline $\mathrm{K}_{2} \mathrm{O}$ & - & - & - & - & - & - & - & - & 0.07 & 0.16 \\
\hline $\mathrm{P}_{2} \mathrm{O}_{5}$ & - & - & - & - & - & - & 46.5 & 45.9 & $<0.04$ & 0.66 \\
\hline $\mathrm{SO}_{2}$ & - & - & - & - & - & - & - & - & $<0.05$ & 0.97 \\
\hline Total & 100.4 & 100.6 & 100. 3 & 100.3 & 100.7 & 99.8 & 99.9 & 100.3 & 99.7 & 99.9 \\
\hline
\end{tabular}

Ak, akimotoite; Holl, hollandite; Lin, lingunite; Maj, majorite; Msk, maskelynite; Px, pyroxene; Pv, perovskite; Rwt, ringwoodite; Stv, stishovite.

Analysis no. 1 and no. 2: Ol in contact with large Rwt (Raman spot 5 in Fig. 1); no. 3 and no. 5: Px in contact with Ak (Raman spot 1 in Fig. 2); no. 4: Px-like glass (gl) composition (Raman spot 1 in Fig. 1); no. 6: vitrified perovskite (v-Pv) within melt pocket (Raman spot 7 in Supplementary Fig. S4); no. 7: matrix merrillite (Mer); no. 8: tuite within melt pocket (Raman spot 2 in Fig. 3); no. 9: maskelynite in melt pocket (Raman spot 1 in Fig. 3); and no. 10: Lin + Maj within melt pocket (Raman spot 3 in Fig. 3).

Martian meteorites of different CRE ages, the source crater produced shergottites of $\sim 0.7-1.1 \mathrm{Ma}$ CRE age that is possibly the largest.

The Tissint meteorite is a unique example of the preservation of a multitude of high-P polymorphs and glasses within a single Martian meteorite. The P-T conditions are tightly constrained from the identified assemblages. However, we feel that the uncertainties encountered in the shock models and the inconsistencies between static and shock experiments, owing to kinetic problems, make sufficient uncertainties in the time dimension. Although the constraints necessary for detailed shock modelling are all present in this meteorite, such a modelling venture is outside the scope of the present study. Notwithstanding, the stronger-than-expected shock metamorphism in Martian meteorites may explain the difficulty in the age dating of shergottites, especially for methods using isotopes of noble gases ${ }^{39,40}$. Furthermore, shock metamorphism can easily affect 'softer materials' (for example, plagioclase). Given the widely dispersed shock melting observed in Tissint, alteration of other soft minerals (carbonates, halides, sulphates and even organics), especially along grain boundaries, might have occurred. This may in part explain the lack of such minerals in Tissint.

\section{Methods}

Petrography. Thin sections were examined using optical microscopy, combined with X-ray maps ( $\mathrm{Si} \mathrm{K} \alpha, \mathrm{Al} \mathrm{K \alpha}, \mathrm{Fe} \mathrm{K} \alpha$ and $\mathrm{Ca} \mathrm{K} \alpha$ ) and the backscattered electron (BSE) images of the sections. The X-ray maps were obtained on a Cameca SX-100 electron microprobe (EMP) at the University of Tennessee. Analytical conditions included an accelerating voltage of $15 \mathrm{keV}$, a beam current of $20 \mathrm{nA}$, with $12 \mu \mathrm{m}$ steps and $75 \mathrm{~ms}$ counting times.

Modal mineralogy in Tissint was obtained using both BSE and X-ray maps and the image processing software ImageJ. The shades of grey of these maps (0-255) were converted to a histogram, displaying unique peaks corresponding to specific minerals. By selecting a peak (threshold), the amount of a given mineral was measured from a given intensity range of these maps. Using the ImageJ output values, the total area of the specific intensity (a particular mineral) was divided with the total area of the whole section providing the area percentage (vol. \%) of a mineral. Errors associated with the measurement of the modal abundances are a function of image resolution and the selection of the threshold values. For confirmation of the results of the above method, we manually contoured the minerals and melt pockets assigning each single phase to a specific colour.

EMP analysis. Major- and minor-element compositions of minerals and glass were obtained using the Cameca EMP. Olivine, pyroxene and oxide-mineral compositions were measured using accelerating voltages of $15-20 \mathrm{keV}$, a $20 \mathrm{nA}$ beam current, $1-2 \mu \mathrm{m}$ beam diameter and counting times of $20 \mathrm{~s}$. Maskelynite, phosphate, sulphide, and glass compositions were determined using a defocused beam with $5 \mu \mathrm{m}$ size, an accelerating voltage of 10 or $15 \mathrm{keV}$, with a $10 \mathrm{nA}$ beam current.
Detection limits are typically $<0.03$ wt $\%$ for $\mathrm{SiO}_{2}, \mathrm{TiO}_{2}, \mathrm{Al}_{2} \mathrm{O}_{3}, \mathrm{MgO}$ and $\mathrm{CaO}$; $<0.04-0.1 \mathrm{wt} \%$ for $\mathrm{FeO}, \mathrm{MnO}, \mathrm{Cr}_{2} \mathrm{O}_{3}, \mathrm{~V}_{2} \mathrm{O}_{3}, \mathrm{NiO}, \mathrm{Na}_{2} \mathrm{O}, \mathrm{K}_{2} \mathrm{O}$ and $\mathrm{P}_{2} \mathrm{O}_{5}$.

Raman spectroscopy. Micro-Raman spectroscopy was conducted on the eight sections of Tissint to verify shock-induced minerals. All Raman spectra were obtained at the Virginia Tech University. The Raman analyses were obtained with a JY Horiba LabRam HR (high resolution) $800 \mathrm{~mm}$ spectrometer, coupled with a $514 \mathrm{~nm}$ Argon-ion laser and a X100 objective. The laser beam was focused at the surface of the samples with an approximate diameter of $1-2 \mu \mathrm{m}$ and at $\sim 5 \mathrm{~mW}$ laser power. This energy is low enough to avoid appreciable destruction of the sample area. Accumulation times were 30,60 and $120 \mathrm{~s}$. For each spot analysis, five spectra were acquired and averaged to give the final spectrum. The Raman spectra were corrected by subtracting a baseline, and then peak positions were calculated applying a least-squares curve fitting of combined Gaussian and Lorentzian functions using the LabSpec software provided by Horiba Scientific. Calculation precision was $\sim \pm 0.2 \mathrm{~cm}^{-1}$. We examined all melt pockets, melt veins and mineral grains near the melt pockets and veins. Raman spectra of the high-P polymorphs were compared with relevant spectra from open access extensive databases (Handbook of Raman spectra, RRUFF ${ }^{41}$ ) and published data. Each highP polymorph verified by Raman spectroscopy has been coupled with EMP spot analysis for a total mineral identification.

\section{References}

1. DeCarli, P. S., Bowden, E., Jones, A. P. \& Price, D. G. Laboratory Impact Experiments Versus Natural Impact Events. GSA Special Paper 356 (eds Koeberl, C. \& McLeod, K. G.) 595-605 (Geological Society of America, 2002).

2. Beck, P., Gillet, P., El Goresy, A. \& Mostefaoui, S. Timescales of shock processes in chondritic and martian meteorites. Nature 435, 1071-1074 (2005).

3. Gillet, P., El Goresy, A., Beck, P. \& Chen, M. High-pressure mineral assemblages in shocked meteorites and shocked terrestrial rocks: mechanisms of phase transformations and constraints to pressure and temperature histories. GSA Special Papers 421, 57-82 (2007).

4. Head, J. N., Melosh, H. J. \& Ivanov, B. A. Martian meteorite launch: high-speed ejecta from small craters. Science 298, 1752-1756 (2002).

5. Irving, A. J. et al. The Tissint depleted permafic olivine-phyric shergottite: petrologic, elemental and isotopic characterization of a recent martian fall in Morocco. 43rd LPSC (Houston, Texas, USA, 2012).

6. Aoudjehane, H. C. et al. Tissint martian meteorite: a fresh look at the interior, surface, and atmosphere of mars. Science 338, 785-788 (2012).

7. Treiman, A. H. et al. Martian dunite NWA 2737: petrographic constraints geological history, shock events and olivine color. J. Geophys. Res. 112, E04002 (2007).

8. Stöffler, D. et al. Shock metamorphism and petrography of the Shergotty achondrite. Geochim. Cosmochim. Acta. 50, 889-903 (1986).

9. El Goresy, A., Wopenka, B., Chen, M. \& Kurat, G. The SAGA of maskelynite in Shergotty. Meteorit. Planet. Sci. 32, 1 (1997).

10. Stöffler, D., Keil, K. \& Edward, R. D. S. Shock metamorphism of ordinary chondrites. Geochim. Cosmochim. Acta. 55, 3845-3867 (1991).

11. Sharp, T. G. \& DeCarli, P. S. Shock effect in meteorites. in Meteorites and the Early. (eds Solar System IILauretta, D. S. \& McSween, H. Y. Jr) 653-677 (University of Arizona Press, 2006). 
12. Tomioka, N., Kondo, H., Kunikata, A. \& Nagai, T. Pressure-induced amorphization of albitic plagioclase in an externally heated diamond anvil cell. Geophys. Res. Lett. 37, L21301 (2010).

13. Fritz, J., Greshake, A. \& Stöffler, D. Micro-Raman spectroscopy of plagioclase and maskelynite in Martian meteorites: evidence of progressive shock metamorphism. Antarct. Meteorite Res. 18, 96-116 (2005).

14. Liu, L. G. Silicate perovskite from phase transformation of pyrope-garnet at high pressure and temperature. Geophys. Res. Lett. 1, 277-280 (1974).

15. Liu, L. G. Post-oxide phases of forsterite and enstatite. Geophys. Res. Lett. 2, 417-419 (1975).

16. Gasparik, T. Phase relations in the tranzition zone. J. Geophys. Res. 95, 15751-15769 (1990)

17. Chen, M., El Goresy, A. \& Gillet, P. Ringwoodite lamellae in olivine: clues to olivine-ringwoodite phase transition mechanisms in shocked meteorites and subducting slabs. Proc. Natl Acad. Sci. USA 101, 15033-15037 (2004).

18. Kato, T. \& Kumazawa, M. Melting experiment on natural lherzolite at $20 \mathrm{GPa}$ : formation of phase B coexisting with garnet. Geophys. Res. Lett. 13, 181-184 (1986).

19. Murayama, J. K., Nakai, S., Kato, M. \& Kumazawa, M. A dense polymorph of $\mathrm{Ca}_{3}\left(\mathrm{PO}_{4}\right)_{2}$ : a high pressure phase of apatite decomposition and its geochemical significance. Phys. Earth Planet. In. 44, 293-303 (1986).

20. Gasparik, T. The role of volatiles in the transition zone. J. Geophys. Res. 98, 4287-4299 (1993).

21. Agee, C. B., Li, J., Shannon, M. C. \& Circone, S. Pressure-temperature phase diagram for the Allende meteorite. J. Geophys. Res. 100, 17725-17740 (1995).

22. Presnall, D. C. Phase diagrams of earth-forming minerals. in Mineral Physics and Crystallography. (ed Ahrens, T. J.) 248-268 (American Geophysical Union, 1995).

23. Xie, X., Chen, M., Wang, D. \& El Goresy, A. NaAlSi ${ }_{3} \mathrm{O}_{8}$-hollandite and other high-pressure minerals in the shock melt veins of the Suizhoo meteorite. Chin. Sci. Bull. 46, 1121 (2001).

24. Xie, Z., Sharp, T. G. \& DeCarli, P. S. High-pressure phases in a shock-induced melt vein of the Tenham L6 chondrite: constraints on shock pressure and duration. Geochim. Cosmochim. Acta 70, 504-515 (2006).

25. Hirose, K. \& Fei, Y. Subsolidus and melting phase relations of basaltic composition in the uppermost lower mantle. Geochim. Cosmochim. Acta. 66, 2099-2108 (2002)

26. Gillet, P., Chen, M., Dubrovinsky, L. \& El Goresy, A. Natural NaAlSi ${ }_{3} \mathrm{O}_{8^{-}}$ Hollandite in the shocked Sixiangkou meteorite. Science 287, 1633-1636 (2000).

27. Tutti, F. Formation of end-member $\mathrm{NaAlSi}_{3} \mathrm{O}_{8}$ hollandite-type structure (lingunite) in diamond anvil cell. Phys. Earth Planet. In. 161, 143-149 (2007).

28. Ohtani, E. et al. Formation of high-pressure minerals in shocked L6 chondrite Yamato 791384: constraints on shock conditions and parent body size. Earth Planet. Sci. Lett. 227, 505-515 (2004).

29. Chen, M., Li, H., Goresy, A. E. L., Liu, J. \& Xie, X. Fracture-related intracrystalline transformation of olivine to ringwoodite in the shocked Sixiangkou meteorite. Meteorit. Planet. Sci. 41, 731-737 (2006).

30. Xie, Z. \& Sharp, T. G. Host rock solid-state transformation in a shock-induced melt vein of Tenham L6 chondrite. Earth Planet. Sci. Lett. 254, 433-445 (2007).

31. Mosenfelder, J. L., Marton, F. C., Ross, II C. R., Kerschhofer, L. \& Rubie, D. C. Experimental constraints on the depth of olivine metastability in subducting lithosphere. Phys. Earth Planet. In. 127, 165-180 (2001).

32. Tschauner, O. et al. Ultrafast growth of wadsleyite in shock-produced melts and its implications for early solar system impact processes. Proc. Natl Acad. Sci. USA 106, 13691-13695 (2009).

33. Fritz, J. \& Greshake, A. High-pressure phases in an ultramafic rock from Mars. Earth Planet. Sci. Lett. 288, 619-623 (2009).

34. Melosh, H. J. Impact Cratering: A Geologic Process. 245 (Oxford University Clarendon, 1989).

35. Nishiizumi, K., Nagao, K., Caffee, M. W., Jull, A. J. T. \& Irving, A. J. Cosmic-ray exposure chronologies of depleted olivine-phyric shergottites. 42nd LPSC, Houston, Texas, USA, \#2371 (2011).

36. Nishiizumi, K., Caffee, M. W. \& Irving, A. J. Exposure history of Tissint: Evidence for 1.1 million year launch pairing with other depleted olivine-phyric shergottites. 75th Annual Meteoritical Society Meeting, Cairns, Australia, \#5349 (2012).

37. Eugster, O., Herzog, G. F., Marti, K. \& Caffee, M. W. Irradiation records, cosmic-ray exposure ages, and transfer times of meteorites. In Meteorites and the Early Solar System II. (eds Lauretta, D. S. \& McSween, H.Y. Jr) 943 829-851 (University of Arizona Press, 2006).

38. Stähle, V., Altherr, R., Nasdala, L. \& Ludwig, T. Ca-rich majorite derived from high-temperature melt and thermally stressed hornblende in shock veins of crustal rocks from the Ries impact crater (Germany). Contrib. Mineral. Petrol. 161, 275-291 (2011).

39. Nyquist, L. E. et al. Ages and geologic histories of Martian meteorites. Space Sci. Rev. 96, 105-164 (2001).
40. Schwenzer, S. P. et al. Helium loss from Martian meteorites mainly induced by shock metamorphism: evidence from new data and a literature compilation. Meteorit. Planet. Sci. 43, 1841-1859 (2008).

41. Downs, R. T. The RRUFF project: an integrated study of the chemistry, crystallography, Raman and infrared spectroscopy of minerals. Program and Abstracts of the 19th General Meeting of the International Mineralogical Association in Kobe, Japan, O03-13 (2006).

42. Greshake, A., Fritz, J. \& Bottger, U. Ringwoodite in the Martian Shergottite Dar Al Gani 670: The role of shearing. 42nd LPSC, Houston, Texas, USA \#1092 (2011).

43. Miyahara, M. et al. Natural dissociation of olivine to ( $\mathrm{Mg}, \mathrm{Fe}) \mathrm{SiO}_{3}$ perovskite and magnesiowüstite in a shocked Martian meteorite. Proc. Natl Acad. Sci. USA 108, 5999-6003 (2011).

44. Walton-Hauck, E. L. \& MacEwan, G. The occurrence of ringwoodite in shock veins of the Elephant Moraine A79001 shergottite. 43rd LPSC, Houston, Texas, USA \#1697 (2012).

45. Langenhorst, F. \& Poirier, J. P. Anatomy of black veins in Zagami: clues to the formation of high-pressure phases. Earth Planet. Sci. Lett. 184, 37-55 (2000).

46. Beck, P., Gillet, P., Gautron, L., Daniel, I. \& El Goresy, A. A new natural high pressure $(\mathrm{Na}, \mathrm{Ca})$-hexaluminosilicate $\left[\left(\mathrm{Ca}_{\mathrm{x}} \mathrm{Na}_{1-\mathrm{x}}\right) \mathrm{Al}_{3+\mathrm{x}} \mathrm{Si}_{3-\mathrm{x}} \mathrm{O}_{11}\right]$ in shocked Martian meteorites. Earth Planet. Sci. Lett. 219, 1-12 (2004).

47. Ozawa, S. et al. Dissociation of pigeonite in shock melt vein/pocket of Martian Shergottites: implications for impact events on Mars. J. P. G. U, Makuhari, Chiba, Japan (2012).

48. Sharp, T. G., El Goresy, A., Wopenka, B. \& Chen, M. A post-stishovite $\mathrm{SiO}_{2}$ polymorph in the meteorite Shergotty: implications for impact events. Science 284, 1511-1513 (1999).

49. Malavergne, V., Guyot, F., Benzerara, K. \& Martinez, I. Description of new shock-induced phases in the Shergotty, Zagami, Nakhla and Chassigny meteorites. Meteorit. Planet. Sci. 36, 1297-1305 (2001).

50. Boonsue, S. \& Spray, J. Shock-induced phase transformations in melt pockets within Martian meteorite NWA 4468. Spec. Lett. 45, 127-134 (2012).

51. Lin, Y., Feng, L. \& Hu, S. High pressure mineral assemblages in the lherzolitic Shergottite Grove Mountains (GRV) 020090. J. P. G. U, Makuhari, Chiba, Japan (2011).

52. Lin, Y., Feng, L., Hu, S., Zhang, J. \& Hao, J. NanoSIMS study of shock-induced melt veins in the enriched lherzolitic Shergottite Grove Mountains (GRV) 020090. J. P. G. U, Makuhari, Chiba, Japan (2012).

53. Imae, N. \& Ikeda, Y. Petrography of new lherzolitic shergottites of Yamato (Y) 000027, Y000047, and Y000097: main lithologies and shock veins. 31st Symposium on Antarctic Meteorites, Tokyo, Japan, 32-33 (2007).

54. Imae, N. \& Ikeda, Y. High-pressure polymorphs of magnesian orthopyroxene from a shock vein in the Yamato-000047 lherzolitic shergottite. Meteorit. Planet. Sci. 45, 43-54 (2010).

55. Mikouchi, T. \& Kurihara, T. Mineralogy and petrology of paired lherzolitic shergottites Yamato 000027, Yamato 000047, and Yamato 000097: another fragments from a Martian 'Iherzolite' block. Polar Sci. 2, 175-194 (2008).

56. Greshake, A. Transmission electron microscopy characterization of shock defects in minerals from the Nakhla SNC meteorite. Meteorit. Planet. Sci. 33, A63 (1998)

\section{Acknowledgements}

This work was funded by NASA Cosmochemistry grants NNX11AG58G to L.A.T NNX10AH486 to H.Y.M., and PGG grant NNX10AU88G to H.J.M., an NSF grant EAR 1019770 to R.J.B. and the Planetary Geosciences Institute at the University of Tennessee. The final revision of this paper was performed by Y.L. at the Jet Propulsion Laboratory, California Institute of Technology. The team effort for this paper consisted of a steep learning curve for the Tennessee scientists, as mentored by Professors Melosh and DeCarli.

\section{Author contributions}

I.P.B. conducted the EMP and Raman measurements, Y.L. and L.A.T. initialized and designed the project, Y.L. calculated the shock duration and growth rate, and P.S.D. modelled the cooling rate of melt pockets. All authors participated in the discussion of results, data interpretation and paper writing.

\section{Additional information}

Supplementary Information accompanies this paper at http://www.nature.com/ naturecommunications

Competing financial interests: The authors declare no competing financial interests

Reprints and permission information is available online at http://npg.nature.com/ reprintsandpermissions/

How to cite this article: Baziotis, I. P. et al. The Tissint Martian meteorite as evidence fo the largest impact excavation. Nat. Commun. 4:1404 doi: 10.1038/ncomms2414 (2013). 